\title{
EKSISTENSI JEMBATAN AMPERA TERHADAP PERKEMBANGAN SOSIAL, BUDAYA, DAN EKONOMI MASYARAKAT ULU PALEMBANG TAHUN 1950-2010
}

\author{
Kabib Sholeh \\ Pendidikan Sejarah Universitas PGRI Palembang \\ Email: habibsholeh978@gmail.com \\ Dina Sri Nindiati \\ Pendidikan Sejarah Universitas PGRI Palembang
}

\begin{abstract}
Abstrak
Penelitian ini bertujuan untuk menganalisis kondisi masyarakat Ulu dan Ilir pra dibangunnya jembatan Ampera, untuk menganalisis sejarah pembangunan jembatan Ampera dan pengaruhnya terhadap perkembangan ekonomi, sosial dan budaya masyarakat Ulu tahun 1962-2010 di Palembang. Metode penelitian yang digunakan adalah metode sejarah (historis), dengan berbagai pendekatan keilmuan seperti pendekatan antropologis, sosiologis, ekonomologis dan geografis. Adapun tahapan pertama, heuristik, pengumpulan sumber atau data dengan observasi, dokumentasi, wawancara dan studi pustaka. Kedua, verifikasi, adalah memilih dan memilah sumber yang terkumpul dengan melakukan kritik intern dan ekstern, ketiga, interpretasi adalah analisis data yang dibantu dengan pendekatan antropologi, sosiologi, ekonomi dan geografis. Keempat, historiografi, tahap terakhir yaitu pemaparan atau penulisan sejarah. Hasil penelitian ini adalah, kondisi pra pembangunan jembatan Ampera tahun 1962, kondisi Ilir dan Ulu mengalami ketidak seimbangan pembangunan dalam berbagai aspek kehidupan seperti ekonomi, sosial dan budaya. Pasca dibangunnya jembatan Ampera tahun 1962 maka besar harapan masyarakat untuk perkembangan masyarakat Ulu yang lebih maju lagi tetapi perkembangan tersebut sampai tahun 2000-an masih berjalan ditempat. Pasca tahun 2000 maka pemerintah dengan akses jembatan Ampera yang mudah untuk menyeberangi ke wilayah Ulu, pemerintah melakukan reklamasi besar-besaran terhadap wilayah Ulu. Dengan demikian masyarakat Ulu mulai merasakan perkembangan dalam bidang ekonomi, sosial dan budaya. Kondisi demikian secara tidak langsung akan berpengaruh terhadap proses menyeimbangkan kehidupan sosial, budaya dan ekonomi masyarakat Ulu dengan Ilir yang berjalan dengan pasti.
\end{abstract}

Kata Kunci: Eksistensi, Jembatan Ampera, Masyarakat Ulu Palembang.

\begin{abstract}
The research method used is historical (historical) method, with various scientific approaches such as anthropological, sociological, economic and geographical approaches. The first stage, heuristics, collection of sources or data with observation, documentation, interviews and literature study. Second, verification, is to select and sort the sources collected by conducting internal and external criticism; third, interpretation is data analysis assisted by anthropological, sociological, economic and geographical approach. Fourth, historiography, the last stage is the exposure or the writing of history. The results of this study were, the condition of the pre-construction of the Ampera bridge in 1962, the condition of Ilir and Ulu experienced an imbalance of development in various aspects of life such as economic, social and cultural. After the construction of the Ampera bridge in 1962, the public expectation for the development of Ulu society is more advanced but the development until the 2000s is still running on the spot. After 2000 the government with easy access to the Ampera bridge to cross into Ulu region, the government conducted a massive reclamation of the Ulu region. Thus Ulu society began to feel the development in the economic, social and cultural fields. Such conditions will indirectly affect the process of balancing the social, cultural and economic life of the Ulu and Ilir people that goes well.
\end{abstract}

Keywords: Existence, Ampera Bridge, Ulu Palembang Community. 


\section{PENDAHULUAN}

Secara geografis kota Palembang dipisahkan oleh Sungai Musi. Masyarakat Palembang menamakan wilayah sebelah utara dari Sugai Musi disebut seberang Ilir "Iliran" dan sebelah selatan Sungai Musi disebut seberang Ulu "Uluan". Pembagian kawasan Ulu da Ilir ini juga dipengaruhi aspek konsep budaya dan konsep wilayah. Pada konsep budaya yang dimaksud wilayah Ulu adalah daerah yang bebas dari penarikan upeti masa Kesultanan, bercirikan agraris, sedangkan daerah Iliran adalah daerah kekuasaan Kesultanan yang wajib membayar upeti kepada Sultan yang bercirikan perdagangan (Alfitri, 2012:30). Dalam konsep wilayah, kata Ulu dan Ilir berbeda pada konsep budaya, Untuk penamaan Iliran dan Uluan wilayah kota Palembang sendiri sudah terjadi lama masa tradisional yang memang secara kebetulan dipisahkan oleh Sungai Musi sehingga masyarakat Palembang berdasarkan kesepakatan untuk wilayah utara Sungai Musi disebut wilayah Ilir dan bagian selatan Sungai Musi disebut wilayah Ulu Palembang.

Secara umum kondisi masyarakat Ilir dan Ulu Palembang baik secara sosialbudaya, ekonomi dan politik pada masa tradisional mengalami perbedaan yang signifikan dari berbagai aspek kehidupan. Kondisi masyarakat seberang Ilir Palembang pada masa tradisional memiliki budaya lebih terbuka terhadap budaya luar dan banyak pedagang asing datang-pergi sehinga terkesan lebih maju dibandingkan wilayah seberang Ulu Palembang yang memiliki budaya masih tertutup pada masa itu (Amilda, 2012:183). Kondisi yang membedakan wilayah Ilir dan Ulu disebabkan berbagai faktor yaitu pertama, dalam perkembangan sejarahnya wilayah Ilir memang sudah menjadi basis pusat perekonomian dan politik bagi penguasapenguasa terdahulu yaitu dari masa Sriwijaya, Kesultanan Palembang dan Keresidenan Kolonial Belanda di Palembang. Dengan demikian masyarakat Iliran dengan mudah dan cepat menerima budaya asing sehingga menjadi masyarakat yang modern.

Faktor kedua, wilayah Iliran merupakan wilayah bertemunya para pedagang asing dengan masyarakat lokal setempat, para pedagang dari pedalaman bertemu dengan pedagang dari luar negeri, sehingga intensitas bertemunya para pendagang tersebut membawa dampak masuknya budaya baru yang dibawa oleh pedagang asing dan secara tidak langsung pola pikir dan budaya masyarakat Ilir berkembang bebas mengikuti kehidupan modernisme (Irwanto, 2010:2). Lain Berbeda dengan wilayah Ulu yang kondisinya berbalik dengan wilayah Ilir pada masa itu. Wilayah seberang Ulu masyarakatnya pada masa itu memiliki budaya yang jauh berbeda akibat tidak ada sentuhan 
budaya luar sehingga keterbelakangan budaya dan tertinggalnya keintlektual masyarakat menjadikan wilayah Ulu lambat untuk berkembang atau maju dibandingkan dengan wilayah seberang Ilir.

Ketermarjinalan masyarakat

Uluan tidak lain ialah akses untuk menuju Ilir yang susah karena akses tranportasi yang dipisahkan oleh sungai yang luas yaitu Sungai Musi. Sebelum ada pembangunan Jembatan Ampera masyarakat Ulu dari pedalaman menggunakan sampan atau perahuperahu kecil untuk menyeberangi sungai Musi menuju Ilir, sambil membawa barang-barang dagangannya untuk dijual di pasar atau pelabuhan yang ada di Ilir, begitu juga ketika ada keperluan lain maka masyarakat harus menyeberangi Sungai Musi dengan biaya penyeberangan yang tidak murah. Biaya jasa tranpostasi kapal atau perahu angkut barang menuju Ilir sangat mahal dan masyarakat harus berebut untuk naik kapal dan tidak jarang harus menunggu berjam-jam. Kondisi yang kacau dan semerawut tersebut mengakibatkan tidak jarang masyarakat jatuh ke sungai akibat penumpang saling berebut dan berempitempitan untuk duduk di kapal (Irwanto, 2006:30 )

Kesenjangan dan ketidak merataan perkembangan pembangunan dalam berbagai bidang antara masyarakat Iliran dan Uluan Palembang, seakan-akan memberikan gambaran ketimpangan dalam berbagai aspek kehidupani yang nyata bagi masyarakat Palembang pada masa itu. Dengan demikian atas permintaan rakyat Palembang untuk membuat pembangunan Jembatan Sungai Musi, yang dapat menghubungkan wilayah Ulu dan Ilir, itu disuarakan pertama kali pada tahun 1961, maka permohonan masyarakat ditindak lanjuti oleh Gubernur Sumatera Selatan kepada Bung Karno yang pada akhirnya disetujui rencana pembangunan jembatan Sungai Musi tersebut (Irwanto, 2011:206).

Pembangunan jembatan Sungai Musi atau nantinya dikenal sebagai Jembatan “Ampera", pertama kali dimulai pada tahun 1962, dan diresmikan langsung oleh Soekarno. Pembangunan jembatan Ampera atau disebut juga jembatan Bung Karno tersebuat sangatlah penting artinya bagi kelancaran hubungan sosial antara masyarakat seberang Ulu dengan seberang Ilir Palembang, dengan harapan pada masa itu untuk memudahkan transportasi bagi masyarakat Ulu untuk berdagang, bersekolah dan aktifitas masyarakat lainnya ke wilayah Ilir yang lebih maju.

Dengan gejala-gejala, peristiwa atau konsep teori yang diuraikan di atas maka peneliti tertarik untuk membahas lebih dalam lagi sebagai kepentingan masyarakat Palembang. Adapun tujuan 
pada pembahasan ini adalah untuk menganalisis kondisi masyarakat Ulu dan Ilir Palembang pra dibangunnya jembatan Ampera, untuk menganalisis sejarah pebangunan jembatan Ampera dan dampaknya terhadap perkembangan ekonomi, sosial, budaya masyarakat Ulu Palembang.

\section{METODE PENELITIAN}

Penelitian ini menggunakan metode Sejarah (metod historis), metode sejarah adalah proses menganalisis secara mendalam dan kritis terhadap rekaman dan peninggalan masa lampau. Atau dapat diartikan proses merekonstruksi peristiwa sejarah menjadi sejarah sebagai kisah (Sjamsuddin, 2012:14).

Adapun langkah-langkah dalam metode penelitian sejarah pertama, heuristik atau dalam bahasa jerman Quellenkunde, adalah suatu kegiatan dalam mencari sumber untuk mendapatkan data-data, atau materi sejarah, atau evidensi sejarah (Sjamsuddin, 2012:67). Peneliti mengumpulkan sumber sejarah atau data dari lapangan yaitu dengan melakukan observasi di lokasi penelitian yaitu Jembatan Ampera dan wilayah Ulu Palembang, melakukan dokumentasi objek dan wawancara. Tahap kedua, Verifikasi Sumber, pada tahap kedua ini penulis melakukan verifikasi sumber sejarah baik sumber dari lapagan maupun sumber studi pustaka yang sudah terkumpul, dengan tujuan untuk mendapatkan sumber yang benar-benar dapat dipercaya dan valid.

Tahap ketiga interpretasi, kegiatan ketiga ini peneliti melakukan interpretasi (penafsiran) atau disebut juga tahap analisis data. Interpretasi atau penafsiran sejarah sering kali disibut juga dengan analisis sejarah (Sjamsuddin, 2012:123). Interpretasi yang digunakan pada penelitian ini yaitu interpretasi dengan pendekatan berbagai aspek bidang keilmuan seperti pendekatan geografis, ekonomologis, sosiologi, antropologis dan interpretasi sintesis. Pada tahap ini peneliti melakukan interpretasi sintesis atas sejumlah fakta mengenai kondisi masyarakat Uluan dalam bidang sosial, budaya dan ekonomi dari faktor kemunduran sampai perkembangannya serta pengaruhnya terhadap pembangunan Jembatan Ampera, yang diperoleh dari sumber-sumber lapangan dan sumber lainnya.

Tahap terakhir Historiografi (Penulisan Sejarah), adalah kegiatan terakhir kali dalam bentuk penulisan dan pemaparan sejarah (Abdurrahman, 1999:67). Pada tahapan terakhir dalam penelitian ini, peneliti melakukan penulisan sejarah dengan tujuan hasil yang ditulis dapat memberikan gambaran peristiwa sejarah dan lainnya. 


\section{HASIL PENELITIAN DAN PEMBAHASAN}

Kehidupan Masyarakat Ilir dan Ulu Palembang Tahun 1950-1960

Dalam bidang ekonomi, masyarakat Ilir Palembang pasca kemerdekaan sampai tahun 1960 tidak berbeda jauh dengan masa-masa pra kemerdekaan. Masyarakat Ulu sebagian besar berdagang, ada juga yang bertani, berkebun, dan pegawai pemerintahan. Wilayah geografis ilir Palembang sangat mempengaruhi kondisi perekonomian

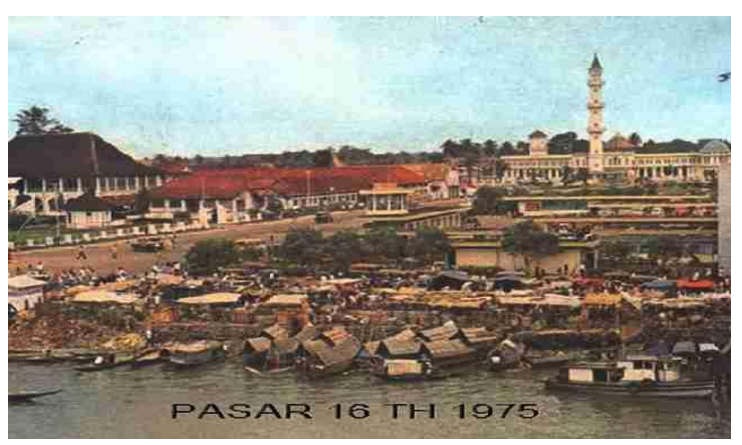

masyarakatnya. Berdagang merupakan salah satu aktifitas ekonomi masyarakat Ilir maupun masyarakat Palembang pada umumnya yang memang dari masa Sriwijaya sudah berkembang dengan pesat seperti perdagangan dilakukan antar pulau bahkan antar negara dengan negara luar seperti Arab, India dan Cina, maka pada kondisi yang sekarang kehidupan bedagang itu sudah menjadi tradisi yang mengakar bagi masyarakat Ilir Palembang.

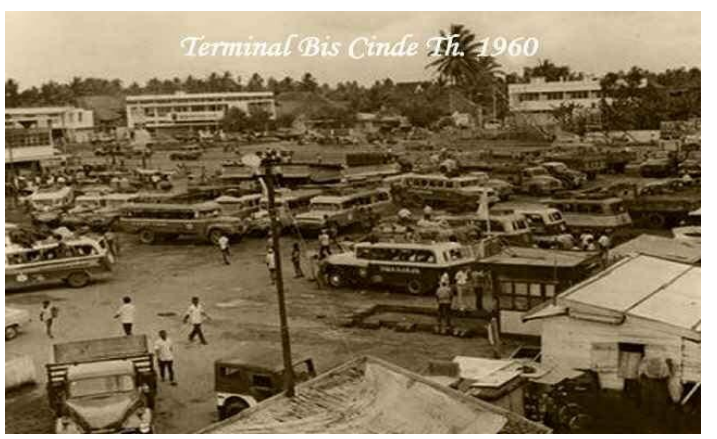

Gambar 1. foto terminal pasar Cinde dan pasar 16 Ilir tahun 1975 (Sumber: Koleksi foto lama oleh Komunitas Pecinta Barang Antik Palembang)

Pada aspek-aspek lain seperti kehidupan sosial budaya masyarakat yang tumbuh terus berkembang untuk menjadi masyarakat madani, maka berkembang juga keberagaman agama tentunya pengaruh dari keberagaman etnis dan suku bangsa asing yang datang ke wilayah Palembang khususnya wilayah Ilir. Para pendatang dari Cina, Arab, India dan Eropa tentu memiliki berbagai latar belakang yang berbeda pula seperti dalam agama, ada yang datang membawa budaya dan agama baru seperti agama Islam, Hindu-Budha,
Kristin dan Konghochu, semuanya ada pada masyarakat Palembang terutama di wilayah Ilir.

Keberagaman agama di wilayah Ilir justru membawa budaya dan keberaragaman baru yang mewarnai kehidupan masyarakat, dan yang lebih penting adalah masyarakat Ilir meskipun keberadaan agama baru yang berasal dari luar yaitu dari masa ke masa justru masyarakat Ilir dan umumnya masyrakat Palembang sangat toleran sekali, sebuah keberagaman dalam agama bagi masyarakat Palembang merupakan suatu 
hal yang biasah dan tidak perlu untuk dipermasalahkan. Sebagian besar masyarakat Palembang adalah beragama Islam, dalam ajaran Islam pun diwajibkan untuk saling menghormati setiap perbedaan agama di masyarakat, maka ajaran Islam yang dianut dan diajarakan sesuai ajaran syariat Islam menjadi landasan pokok bagi masyarakat Ilir Palembang dalam menyikapi sebuah perbedaan.

Sedangkan wilayah Ulu Palembang, secara geografis terletak pada sebelah selatan sungai Musi yang membentang dari barat ke timur, dengan perbatasan sebelah barat wilayah Ulu berbatasan dengan Kabupaten Ogan Ilir, sebelah timurnya berbatasan dengan Kabupaten Banyuasin dan Selatannya berbatasan dengan Kabupaten Banyuasin. Secara umum letak topogfaris wilayah Ulu beragam, sebagian wilayahnya dataran tinggi dan sebagian besarnya dataran rendah atau wilayah rawa-rawa. Wilayah Ulu pada awalnya sebelum dilakukan pemekaran, pada masa prakemerdekaan sangat luas karena belum ada pembagian wilayah kabupaten baru, sehingga wilaya Ulu untuk kondisi pasca kemerdekaan memiliki batas-batas yang jelas dengan wilayah kabupaten tetangganya. Untuk kawasan Ulu ini juga dilalui sungaisungai besar yang bermuara di sungai Musi seperti sungai Ogan dan Komering yang alirannya sampai mencapai masuk kewilayah pedalaman jauh menuju wilayah hulunya sugai atau disebut wilayah Ogan.

Masyarakat Ulu dalam hal budaya, masa tradisional, biasa disebut masyarakat yang berada di luar perkotaan Palembang atau wilayah pedalaman Sumatera Selatan, atau masa keresidenan Palembang pada masa lalunya (Ismail, 2014:1-2). Pandangan demikian tentu berdasarkan konsep budaya yang memang secara topografis wilayah Ulu terletak pada bagian selatan Palembang yang kebetulan terpisah dengan wilayah Ilir dan sungai Musi yang menjadi pemisahnya. Sungai Musi yang mengalir dari barat ke timur tersebut tentu membelah wilayah Palembang dengan berbagai konsekuensi budaya sosial masyarakat Palembang yang biasanya disebut masyarakat Iliran dan masyarakat Uluan. Pemisahan oleh sungai besar tersebut tentu membawa dampak dalam berbagai perkembangan kemajuan masayarakat dalam bidang sosial, budaya, ekonomi, politik dan yang lainnya, seperti halnya dalam bidang ekonomi secara umum wilayah Uluan merupakan wilayah yang serasa termarjinalkan dan tidak mengalami perkembangan ekonomi yang positif, kondisi itu berlangsung dari masa ke kemasa termasuk masa pasca kemerdekaan Indonesia kurang lebih sampai tahun 1960-an. 
Kehidupan masyarakat Ulu Palembang dalam bidang perekonomiannya sedikit berbeda dengan masyarakat yang tinggal di wilayah Ilir Palembang yaitu pada masyarakat Ulu justru mengalami kemunduran dalam bidang ekonomi dibandingkan masyarakat Ilir Palembang.

Kemunduran dan kurang berkembangnya dalam bidang ekonomi masyarakat Ulu adalah disebabkan beberapa faktor diantaranya adalah faktor kesenjangan dan faktor budaya. Pada faktor kesenjangan disini memiliki beberapa alasan mulai kurang lancarnya hubungan kontak langsung antara masyarakat Ulu dan Ilir, dalam masyarakat hubungan sosial itu sangat penting karena kegiatan apapun akan terasa mudah dan terbantu apabila hubungan antara satu kelompok dengan kelompok lainnya berjalan dengan baik dan saling mengisi antara satu kelompok dengan kelompok lainnya.

Tentu hubungan antara masyarakat Ulu dan Ilir tidak berjalan dengan baik disebabkan karena dua kelompok masyarakat ini telah dipisah oleh satu sungai besar yaitu sungai Musi. Transportasi untuk menuju Ilir atau sebaliknya pada pasca kemerdekaan sampai tahun 1960-an masih menggunakan prahu atau kapal-kapal kecil yang sifatnya masih sederhana dan jauh dari teknologi modern, dan yang paling berpengaruh besar pada masa itu belum dibangunnya jembatan Ampera di sungai Musi. Penghubung antara masyarakat Ulu dan masyarakat Ilir yang belum ada dan masih menggunakan alat transportasi air yang sederhana maka persoalan tersebut menjadi permasalahan yang muncul sehingga adanya kesenjangan sosial yang tajam antara Ilir dan Uluan terutama dalam bidang ekonomi.

Selain bertani, kehidupan masyarakat Ulu juga melakukan aktifitas ekonomi dalam bentuk mencari ikan dengan cara memancing atau dengan cara tradisional lainnya yang dilakukan di sungai-sungai anak sungai Musi maupun di sunga Musi sendiri. Selain kehidupan nelayan, berdagang sebenarnya kegiatan yang dilakukan oleh masyarakat Ulu dari masa ke masa, seperti sebagian masyarakat Ulu menjual barang-barang komoditas dagang dari pedalaman yang dibawa ke pasar 16 Ilir sekarang. Barang-barang dagangan yang diperdagangan oleh masyarakat Ulu yang diambil dari tempatnya pedalaman seperti lada, kayu manis, padi, buah-buahan dan sayursayuran, semua barang-barag dagang tersebut dibawa oleh para pedagang menuju wilayah pasar seberang Ilir dengan menggunakan kapal atau perahu kecil-kecil (perahu Kajang), dengan perjalanan yang sangat membahayakan melalui sungai Musi. 
Tidak jarang pula perahu tenggelam beserta barang-barang dagannya ada juga yang mengalami kerampokan oleh para perompak di sungai sehingga para pedagang tersebut banyak mengalami kerugian besar baik secara meteri maupun non materi. Maka secara ekonomi masyarakat Ulu merupakan masyarakat yang belum maju yang sebenarnya pasca kemerdekaan sampai 1960-an, masyarakat Ulu hanya bejalan ditempat, belum bisa untuk berdagang seperti masyarakat Ilir, para pedagang asingpun tidak ada yang berdagang ke wilayah Ulu semuanya berfokus datang di wilayah Ilir sebagai tempatnya wilayah bisnis yang sangat maju dan ramai.

Dalam kehidupan sosial-budaya masyarakat Uluan Palembang sebelum dibangunnya jembatan Ampera di sungai Musi, maka mengalami beberapa ketermarjilanan yang diakibatkan kurangnya kontak budaya dan kontak sosial dengan budaya Ilir maupun budaya asing. Kondisi budaya yang statis tanpa dinamis membuat masyarakat Ulu terasa terpinggirkan dalam hal apapun sehingga rasa minder dan tidak percaya diri masyarakat Ulu terhadap masyarakat luar termasuk orang-orang Ilir. Masyarakat Ulu sering disebut sebagai masyarakat yang memiliki budaya statis bahkan cenderung menurun, disebut juga masyarakat Ulu kurang dalam dunia pendidikan dan perkembangan lainnya.
Kondisi yang demikian terjadi pasca kemerdekaan atau sebelum dibangunnya jembatan Ampera di sungai Musi. Faktor kesenjangan dalam kontak budaya dan kontak sosial antara masyarakat Ulu dengan masyarakat luar ditambah lagi penghubung atau jembatan di sungai Musi belum dibangun sehingga mempersulit masyarakat Ulu maupun Itir dalam melakukan kontak sehingga ketimpangan antara dua wilayah tersebut benar-benar menunjukan perbedaan dalam berbagai bidang.

Sejarah Pembangunan Jembatan Ampera di Sungai Musi

Secara geografis wilayah Palembang dipisahkan oleh sungai Musi menjadi wilayah Ulu dan Ilir. Masyarakat Palembang membutuhkan segera dibangunnya jembatan Musi yang dapat menghubungkan antara masyarakat Ulu dan Ilir. Tidak hanya meghubungkan secara fisik, bagi masyarakat Palembang kondisi ketimpangan sosial dan ketidak merataan perkembangan masyarakat antara Ulu dan Ilir, diyakini disebabkan karena belum adanya penghubung jembatan sehingga pembangunan sosial, budaya ekonomi masyarakat Ulu dan lainnya masih berpusat di wilayah Ilir.

Sebelum dibangunnya jembatan Ampera di sungai Musi, hubungan antara masyarakat Ulu dan Ilir hanya dapat menggunakan perahu atau kapal kecil, jasa penyeberangan dari Ulu menuju Ilir 
sudah hilir mudik mengangkut masyarakat Ulu untuk keperluan sekolah, menjual barang-barang dagangan di pasar 16 Ilir, dan ada satu jasa layanan penyeberangan yang banyak ditumpangi pada masa itu seperti kapal Marie (Irwanto, 2005:25). Penggunaan jasa peneyeberangan dengan menggunakan kapal Marie pertama kali digunakan pada masa Belanda, tetapi pasca kemerdekaan kapal Marie tersebut sudah berangsurangsur tidak dipakai atau tidak digunakan lagi.

Sebenarnya isu dan rancangan mengenai pembangunan jembatan Musi tersebut sudah pernah direncanakan pada masa pemerintahan kolonial, yaitu pada masa walikota Le Cocq d'Armandvile pada tahun 1924 (Akib, 1956:129). Pada masa ini walikota Palembang pada masa kolonial sudah memiliki ide untuk membangun sebuah jembatan raksasa yang menghubungkan antara seberang Ulu dengan Ilir, dan permasalahan ini pada masa itu sudah menjadi persoalan yang penting untuk direalisasikan tetapi sayangnya sampai runtuhnya kekuasan kolonial Belanda di Palembang, rencanan tersebut hanya tinggal rencanan saja tanpa ada realisasi yang nyata sampai akhirnya masa kemerdekaan Indonesia.

Pada masa pasca kemerdekan Indonesia sekitar tahun 1950-1960-an, maka masyarakat Palembang menggulirkan keinginanya melalui dewan kota Palembang untuk merealisasikan pembangunan jembatan Musi tersebut. Menurut sumber berita koran Yogyakarta Kedaulatan Rakyat (19 Juli 1960), yang memuat berita tentang akan dilaksanakannya pembangunan jembatan modern di atas sungai Musi Palembang (Irwanto, 2005:11). Sayangnya tidak mencantumkan besaran total pembiayaan pembangunan jembatan, yang digadang-gadang oleh masyarakat Palembang sebagai proyek terbesar di Palembang pada masa itu.

Pasca berakhirnya rapat, para tokoh tim perumus pembangunan jembatan Musi berkumpul untuk membahas pembangunan jembatan Musi yang sudah disetujui anggota DPRD. Pada tahun 1957, para tim tersebut belum juga dapat mengumpulkan modal yang besar. Tetapi ada beberapa orang yang mengusulkan agar melapor ke pemerintah pusat. Maka sebagian tim perumus tersebut seperti Gubernur Bastari, kolonel Harun Sohar, walikota Ali Amin dan Indra Caya, ingin bertemu langsung Bung Karno di Istana Negara.

Dengan niat yang bulat maka pada akhirnya pertemuan tersebut terlakasana dan bung Karno menyetujui rencana pembangunan jembatan Musi. Secara kebetulan pada masa itu Indonesia akan menerima dana pamapasan perang dari pemerintah Jepang, dan Bung Karno berencana dana 
pamapasan perang itu yang akan menjadi modal dalam pembangunan jembatan Musi nantinya.

Pada tahun 1958 Soekarno sudah mendapatkan kabar dari perdana menteri Djuanda bahwa sekitar 20 juta dollar tahap pertama pampasan Jepang akan segera disetujui. Berdasarkan dari kabar inilah Soekarno menyusun salah satu rencananya membangun jembatan sungai Musi. Pada tahun 1960, dana benar-benar cair dan dimulailah jembatan Musi. Soekarno meminta kepada arsitek jembatan Musi ini agar membangun boulevard di kedua sisi jembatan. Jembatan Musi dibangun dengan arsitek Jepang yang memang amat paham bagaimana membangun Jembatan di wilayah dengan resiko gempa tinggi. Soekarno meminta agar jembatan itu bisa bertahan 100 tahun bahkan lebih, ahli-ahli Jepang itu menyanggupinya.

Pada tahun 1965, Jembatan itu selesai dibangun dan rakyat Palembang memberikan nama Jembatan itu “Jembatan Bung Karno". Sebagai rasa terima kasih mereka kepada presidennya yang telah berjuang membangun Jembatan di tengah kota Palembang dan menjadi kebanggaan rakyat Palembang. Tapi konspirasi Gestapu 65 membuat Soekarno terpuruk, saat ramai-ramainya demonstrasi 1966, jembatan Bung Karno diganti namanya menjadi "Jembatan Ampera" yang artinya Amanat
Penderitaan Rakyat. Amanat penderitaan rakyat yang dimaksud merupakan penderitaan masyarakat Palembang karena sudah sekian puluh tahun dijajah oleh kolonial Belanda dan pada tahun 1942 dijajah oleh tentara Jepang. Dengan peristiwa yang dianggap masyarakat Palembang sangat menyedihkan dan menyengsarakan rakyat maka setelah para penjajah tersebut tidak ada lagi di Palembang serasa senang dan merdeka, dan jembatan Ampera merupakan sebuah simbol kemerdekaan dari amanat penderitaan rakyat Palembang.

Pada awalnya jembatan penghubung sungai Musi antar Ulu dan Ilir ini terdapat perbedaan penempatan, menurut Yudi (ketua KOMPAK), pada awalnya ada tiga tempat sebagi lokasi pembangunan jembatan di sungai Musi yang diajukan oleh beberapa tokoh tim pembangunan jembatan Ampera. Pendapat tersebut didukung oleh Irwanto dalam bukunya "Palembang Kota Vanisia dari Timur" yang menjelaskan setidaknya ada tiga tempat lokasi yang diajukan sebagai tempat dibangunnnya jembatan di sungai Musi, pertama pembangunan jembatan Musi tersebut berada pada tepat pada darmaga di 16 Ilir Palembang terus memanjang menyeberangi sungai musi masuk wilayah terminal 7 Ulu. Opsi kedua, jembatan Ampera akan ditempatkan oleh sebagian masyarakat Palembang di wilayah Tangga 
Takat bagian laut di daerah Plaju pada seberang Ulu membentang ke sungai Musi menuju terusan jalan Pusri sekarang atau masuk wilayah Kalidoni. Pada opsi yang ketiga, sebagian masyarakat Palembang mengajukan lokasi pembangunan jembatan musi pada sekitar kampung 4 Ulu laut dengan lurus melintang ke seberang Ilir di wilayah pasar Sekanak sebagai lurusan jalan Temon wilayah Ilir Palembang.

Dari tiga pendapat megenai penempatan lokasi awal peletakan pertama kali jembatan Musi seperti yang diuraikan pada bagian atas merupakan suatu opini yang sah-sah saja disampaikan oleh sebagian masyarakat Palembang, karena semua pendapat yang diajukan tersebut memenuhi kriteria. Tetapi pada akhirnya tiga pendapat tersebut tidak semuanya digunakan, dan cukup satu yang direstui oleh tim perumus pembangunan jembatan Musi sekaligus medapat izin dari Soekarno bahwasannya jembatan Musi yang dimaksud akan dibangun pada lokasi opsi yang pertama, atau lokasi jembatan Ampera sekarang, yang dimulai dari wilayah 7/10 Ulu sampai menuju seberang wilayah pasar 16 Ilir dan terus lurus menuju jalan Soederman. Meskipun ada sebagian masyarakat kecewa dengan keputusan tersebut tetapi pada akhirnya semua menerima dan menyetujui bahwasannya semua pendapat tujuanya sama yaitu demi kesejahteraan masyarakat Palembang terutama masyarakat Ulu. Setelah dibangunnya jembatan Musi nanti, besar harapan masyarakat Palembang adanya peubahan yang mendasar terutama mengenai pemerataan dalam perkembangan ekonomi masyarakat yang ada diwilayah ulu.

Setelah Soekarno memutuskan untuk penetapan lokasi pembangunan jembatan Musi yaitu satu dari tiga opsi yang disuarakan masyarakat Palembang, maka didukung pula oleh masyarakat dan menyetujui kalau pembangunan jembatan Musi tersebut dibangun tepat lokasi jembatan Ampera yang ada saat ini. Tepatnya pada tanggal 10 April 1962 Soekarno meresmikan peletakan pancang tiang jembatan Musi untuk yang pertama kalinya, dengan suara sorak-sorak masyarakat Palembang yang menyaksikan peresmian pembangunan jembatan Musi tersebut maka dengan semangat tekat masyarakat Palembang terlihat dengan jelas atas kegembiraan yang dirasakan.

Menurut bapak Maman Abdurahman, pembangunan jembatan Musi pada masa itu adalah sebuah simbol datangnya secerca angin segar terutama bagi masyarakat Ulu, karena dengan jembatan Musi yang nantinya dapat membuat akses tranportasi yang bisa menghubungkan saudara, kerabat, keluarga dan lainnya terhadap masyarakat Ilir maka akan dengan mudah 
mereka laksankan. Tetapi yang lebih penting lagi, adanya jembatan Musi setelah selesainya nanti besar harapan untuk membuat kesejahteraan masyarakat Ulu dan Ilir tercapai dan kesenjangan dalam bidang sosial, ekonomi, budaya dan lainnya dengan cepat akan berubah lebih maju lagi.

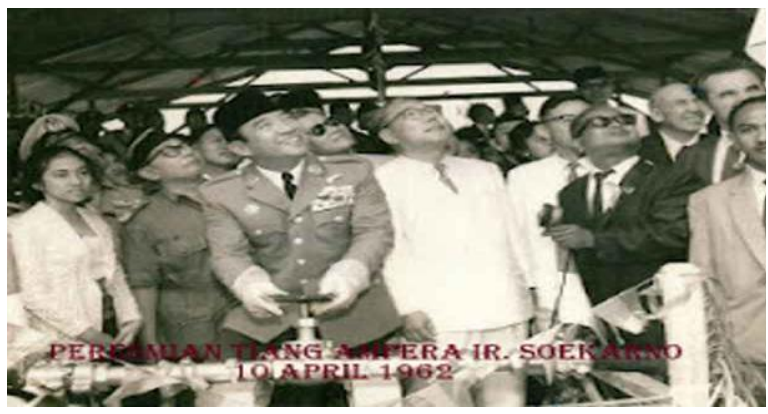

Gambar 1. Foto peresmikan pembangunan jembatan Ampera tahun 1962 (Sumber: foto koleksi Komunitas barang antik Sriwijaya)

Salah satu isi dari pidato Soekarno, dalam acara peresmian pembangunan jembatan Ampera yang pertama kali menyatakan bahwa pembangunan jembatan tersebut diharapkan tidak akan lama selesainya dan ditargetkan tahun 1964 jembatan Ampera sudah rampung dikerjakan (Arsip, 1962). Selain itu bung karno menyatakan bahwa pembangunan jembatan Musi ini bukan hanya sekedar membangun bangsa ini secara fisik saja, tetapi lebih dari itu yaitu membangun karakter dan kepercayaan diri masyarakat terutama masyarakat Palembang untuk lebih semangat lagi dalam membangun dan mengisi kemerdekaan Indonesia yang terbilang masih berumur sangat muda. Maka dengan dibangunnya jembatan Musi di Palembang akan menunjukan kepercayaan diri yang tinggi untuk menjadi bangsa Indonesia menjadi bangsa yang besar, tahan akan ujian yang sedang dihadapi dan yang lebih penting adalah masyarakat Palembang dengan dibangunnya jembatan Musi tersebut menjadi dasar akan perkembangan sosial, budaya, ekonomi, pedidikan dan politik masyarakat Palembang yang lebih maju lagi.

Setelah peresmian dimulainya pembangunan jemabatan Ampera oleh bung Karno tahun 1962, maka pembangunan segera dimulai dengan berbagai konsep dan arsitek langsung dari Jepang yaitu untuk membuat tiangtiang dasar jembatan terlebih dahulu. Pada pembangunan jembatan Musi tersebut juga secara langsung diawasi oleh Soekarno melalui utusannya yang setiap bulan datang dan pergi ke Palembang dari Jakarta yaitu Prof. Ir. Sutami, seorang pakar beton pratekal terkenal yang berasal dari Indonesia (Irwanto, 2005:5).

Bung Karno melalui utusannya tersebut selalu berpesan dan berharap pembangunan jembatan Musi di Palembang untuk diawasi dengan sungguh-sungguh karena bung karno dalam kesempatan peresmian awal pembangunan jembatan tersebut pernah mengatakan bahwasannya Palembang merupaka kota yang sangat beruntung 
akan memiliki jembatan yang megah dan besar, ia menambahkan juga pembangunan jembatan ini adalah proyek pembangunan jembatan terbesar yang pernah ada di Indonesia pada masa itu, biayanyapun berasal dari dana pampasan perang dari pemerintah Jepang karena kalah perang sebagai pertangungjawaban tentara Jepang yang sudah menjajah Indonesia kurang lebih 3,5 tahun dan pada akhirnya ia kalah dengan tentara sekutu pada Perang Dunia II tahun 1945.

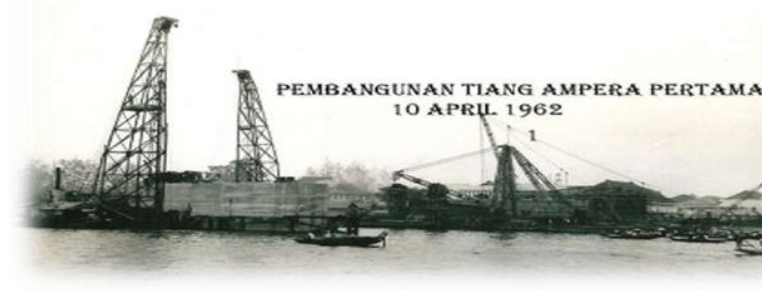

Gambar 2. Foto pembangunan tiang pancang jembatan Ampera (Sumber: foto koleksi Komunitas Pecinta Barang Antik Sriwijaya Palembang)

Pembangunan tiang pancang jembatan Musi seperti terlihat pada gambar di atas menunjukan memang pembangunan jembatan ini seperti yang dikatakan bung Karno ini merupakan proyek besar yang pernah ada di Palembang pasca kemerdekaan Indonesia. Terlihat peralatan-peralatan alat berat didatangkan langsung dari luar dengan arsiteknya sendiri dari Jepang yang menunjukan bahwasannya pembangunan jembatan ini bukan hanya membuat sebuah jembatan yang hanya sekedar dapat menghubungkan masyarakat Ulu dengan Ilir saja, tetapi lebih dalam lagi sebagai bentuk nilai pembangunan karakter yang akan dapat menyambungkan kehidupan masyarakat Palembang untuk masa itu dan masa yang kan datang, jadi membangun yang dimaksud buka hanya membangun fisik saja tetapi memang untuk membangun karakter optimis masyarakat untuk mencapai kemajuan sesuai tujuan negara Indonesia.

Setelah diselesaikannya pembuatan tiang-tiang pancang jembatan, maka dilanjutkan membuat badan jembatan. Dalam pembuatan bagian ini juga seperti yang diharapkan oleh bung Karno bahwasannya ia menginginkan jembatan Musi ini dibuat indah dan kokoh tentunya, keinginan ini disampaikan oleh Soekarno ketika tim perumus pembuatan jembatan Musi pertama kali berkunjung menemui Soekarno di Jakarta. Maka sesuai saran dan instruksi Soekarno, arsitek dan tim pembangunan jembatan Musi membuat badan jembatan dengan konstruksi yang sedikit berbeda yaitu pada bagian tengah badan jembatan dibuat tiang menara dengan ketinggian kurang lebih 63 meter dan jarak antara kedua tiang menara jembatan kurang lebih mencapai 75 meter. 


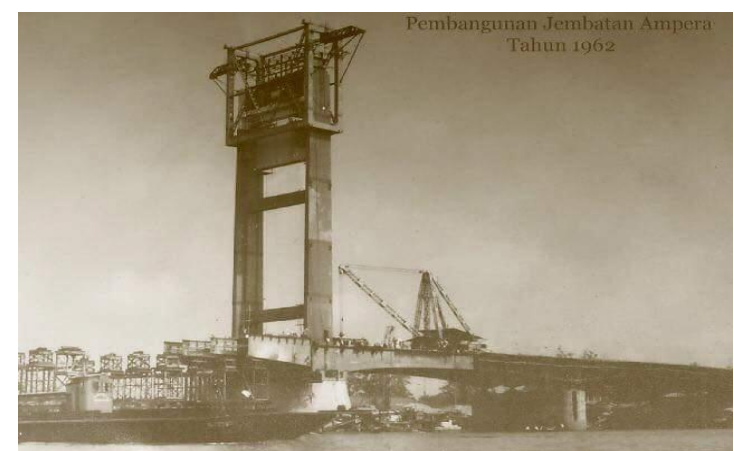

Gambar 3. Foto pembangunan menara tengah jembatan (Sumber: foto koleksi Komunitas Pecinta Barang Antik Sriwijaya Palembang)

Pada gambar di atas tampak proses pembuatan tiang menara jembatan Musi yang diletakkan pada bagian tepat di tengah jembatan. Tujuan utama dalam pembuatan tiang menara jembatan ini adalah untuk mengangkat badan jembatan pada bagian tengah dengan lebar berjarak kurang lebih 75 meter, tujuan naik turunnya pada bagian tengah badan jembatan adalah sebagai jalan kapal-kapal besar yang ketinggiannya mencapai jembatan. Sungai Musi mengalami pasang surut sehingga pada saat pasang, air sungai tersebut mengalami kanikan pada permukaan sungai begitu juga pada saat sungai surut, permukaan air sungai mengalami surut. Kondisi demikian berdampak pada kapal-kapal yang melewati sungai Musi terutama pada kapal-kapal besar seperti kapal tongkang, kapal pembawa barang-barang tambang batu bara atau kapal besar lainnya ketika melewati jembatan Musi akan menabrak jembatan tersebut, sehingga perlunya pada bagian tengah jembatan dibuat posisi naik-turun ketika kapal-kapal besar melewati jembatan. Maka pembangunan jembatan dengan tiang menara tersebut memiliki fungsi yang efektif bagi kapal-kapal besar yang melewati jembatan sehingga tidak akan terganggu dan lancar.

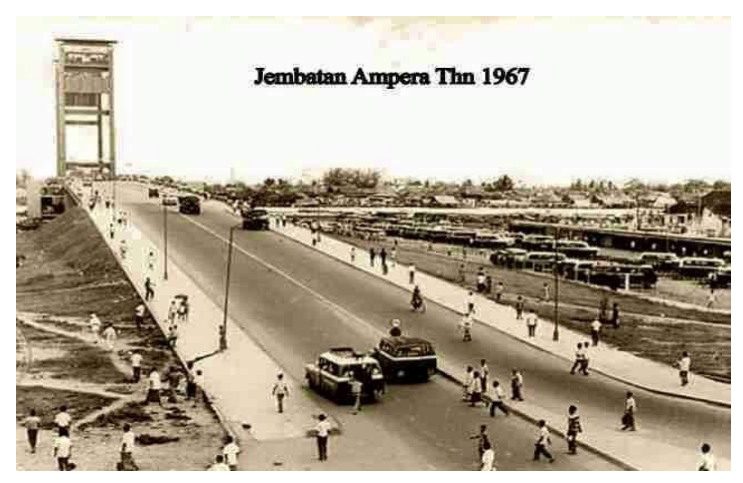

Gambar 4. Foto jembatan Ampera tahun 1967 (Sumber: foto koleksi Komunitas Pecinta Barang Antik Sriwijaya Palembang)

Pada tahun 1965-an jembatan Musi tersebut sudah rampung pengerjaanya dan hasil yang sangat memuskan yaitu dengan panjang jembatan dari daratan wilayah Ilir sampai daratan Ulu mencapai 1 kilo lebih 117 meter, dengan lebar badan jembatan 22 meter. Selesainya pembangunan jembatan Musi tersebut maka akan diadakan peresmian pembukaan jalan jembatan Musi sebagai jalan umum yang dilewati oleh masyarakat Palembang. Peresmian pengoperasian jembatan Musi diberitakan oleh koran Nasional (Selasa 16 Nopember 1965), dalam berita koran tersebut yang meresmikan pengoperasian jembatan sebagai jalan umum yang siap dibuka bukan oleh Soekarno langsung 
tetapi oleh Gubernur Sumatera Selatan Brigdjen A.H. Jazid Bastomi. Alasan Soekarno tidak dapat hadir dan mewakilkan kepada Gubernur Sumatera Selatan adalah karena faktor politik dan peristiwa G30 SPKI di Jakarta sehingga Soekarno memutuskan untuk diwakilkan kepada Gubernur Sumatera Selatan Jazid Bastomi.

Pada kesempatan acara peresmian pembukaan jembatan Musi, Gubernur Sumatera Selatan dalam pidatonya ia menyatakan bahwa rakyat Sumatera Selatan pada hari ini telah menerima hadiah dari presiden Indonesia bung Karno yaitu berupa jembatan Musi yang mewah, kokoh dan indah. Menurut Bastomi jembatan Musi ini dibangun pada jantung kota yang megah dan kokoh sebagai jembatan kebanggaan masyarakat Sumatera Selatan, maka dengan demikian Gubernur Bastomi, sebagai penghormatan dan ucapan terimakasih kepada bung Karno, maka jembatan Musi ini dinamakan jembatan bung Karno. Berita tentang penamaan jembatan Bung Karno juga diberitakan pada koran Suluh Indonesia (14 Desember 1965), penamaan jembatan bung Karno sebelumnya sudah dimusyawarahkan di DPRD GR dan para anggota dewan tersebut secara aklamasi juga menyetujui pengajuan nama jembatan musi dengan nama jembatan Bung Karno (Irwanto, 2005: 8). Tentu penamaan jembatan Bung Karno, sebagai bukti rasa terimkasih masyarakat Sumatera Selatan kepada presiden Soekarno, telah membangun jembatan Musi yang sangat dibutuhkan dan dinantinantikan oleh masyarakat Sumatera Selatan.

Pada masa Orde Baru, nama jembatan Bung Karno diubah namannya menjadi jembatan Ampera tentu oleh pemerintah masa Orde Baru dan disetujui sebagai masyarakat Sumatera Selatan sehingga nama jembatan Ampera sampai sekarang bukan lagi jembatan Bung Karno. Perubahan nama tersebut tentu karena berbagai faktor dari kalangan pemerintah dan masyarakat, ada yang menyatakan faktor politik masa Orde Baru yang tidak menyetujui nama jembatan Musi tersebut dinamakan jembatan bung Karno karena efek politik peristiwa GESTOK dan faktor-faktor yang lainnya. Sedangkan menurut Irwanto, perubahan nama tersebut disebabkan karena dahulunya di samping sisi kanan kiri jembatan wilayah ilir Palembang sering dijadikan sebagai tempat berkumpulnya para pejuang mahasiswa yang mengatasnamakan sebagai amanat penderitaan rakyat, dengan demikan jembatan Musi yang dahulunya bernama jembatan Bung Karno serasa kurang tepat dan yang tepat sebagai simbol penderitaan rakyat Sumatera Selatan maka namanya dirubah menjadi jembatan AMPERA (Amanat Penderitaan Rakyat). Penamaan jembatan Ampera 
tersebut tentu didukung oleh pemerintahan Orde Baru yang jmenyetujui perubahan nama jembatan tersebut menjadi jembatan AMPERA.

\section{Pengaruh Perkembangan Masyarakat} Seberang Ulu pasca Pembangunana Jembatan Ampera 1962-2010

Perkembangan suatu wilayah atau kota baik bidang sosial, budaya, ekonomi dan politik tentu banyak yang mempengaruhi, atau faktor-faktor yang mendorong perubahan tersebut. Salah satunya karena ada faktor fisik (geografis) yang berpengaruh pada perkembangan wilayah tersebut (Branch, 1995:37). Tidak hanya fisik saja sebenarnya, faktor politik, ekonomi, sosial dan faktor lainnya dapat juga berpengaruh besar terhadap perubahan wilayah, dan yang menarik lagi perkembangan tersebut tidak akan terjadi apabila hanya sekedar menjadi faktor penyampingan saja tiada berkelanjutan yang lebih positif lagi. Sedangkan perkembangan kota lebih cenderung dianalisis dari perkembangan penduduk perkotaan. Semuan unsur tersebut saling berkaitan dan mempengaruhi di dalam tampilan tercermin dari bentukan fisik perkotaan yang mengemban fungsi-fugsi tertentu.

Berdasarkan

potensi

perkembangan sekitarnya, ada tiga jenis perkembangan kota. Pertama, adanya daya tarik dari luar kota, terutama daerah dengan kegiatan ekonomi yang menonjol seperti di sekitar pelabuhan eksport-import dan daerah penyangga (hinterland) yang subur. Harga tanah disekitar jalur ini akan lebih mahal dibandingkan harga tanah yang ada di daerah pegunungan. Kedua adalah faktor kemampuan kota itu sendiri untuk memiliki berbagai pusat-pusat industri dan pusat perdagangan sehingga secara tidak langsung faktor ini sangat mempengaruhi perkembangan sosial, budaya dan ekonomi suatu kota. Ketiga adalah adanya pengembangan wilayah atau kota dari segala penjuru yang akan menjadi kota metropolitan (Budiharjo, 1997:23).

Dari teori yang diungkapkan di atas maka untuk kota Palembang memiliki faktor-faktor tersebut, terutama pada wilayah Ilir Palembang. Tetapi untuk wilayah Ulu sepertinya memiliki sebagian faktor tersebut, dan untuk faktor seperti wilayah pusat industri, pengembangan wilayah kota dan faktor lainnya seprtinya masih perlu dikembangkan lagi dengan intensif. Maka dengan demikian perkembangan masyarakat Ulu dalam aspek sosial, budaya dan ekonomi untuk wilayah Ulu pada tahun awal-awal kemerdekaan serasa masih jauh dari harapan dibandinkan wilayah seberang Ilir Palembang.

Kondisi masyarakat wilayah Ulu yang dengan berbagai kekuarangannya 
maka adanya pembangunan jembatan Ampera tahun 1962 sepertinya telah memberikan harapan baru bagi masyarakat Ulu termasuk dalam berbagai aspek kehidupan. Masyarakat Ulu pra pembangunan jembatan Ampera, telah mengalami kehidupan yang statis dalam berbagai aspek dan biasa orang menyebut orang Uluan adalah masyarakat yang dianggap orang dari pedalaman. Kehidupan seperti itu berlangsung lama dan butuh waktu yang cukup untuk melakukan perkembangan masyarakat.

Setelah selesainya pembangunan jembatan Ampera maka akses masuk ke Ulu menuju Ilir dan sebaliknya sangat mudah, dan yang lebih utamanya adalah kendaran seperti mobil, motor, becak dan alat transpotasi lainnya dapat menyeberangi sungai Musi melalui jembatan Ampera. Aktifitas masyarakat Ulu yang awalnya terhalang dengan sungai, kini terbuka sudah akses tersebut dengan mudah. Kegitaan perdagangan yang dilakukan masyarakat Ulu tidak lagi menggantungkan kehidupannya pada jalur transportasi air, dengan menggunakan kapal barang untuk mengankut barang-barang dagangannya untuk dibawa ke pasar seberang Ilir. Tetapi sudah beralih menggunakan jalur darat yaitu melalui jembatan Ampera. Tidak hanya para pedagang yang merasakan bahagia tetapi masyarakat Ulu lainnya merasa senang gembira dengan dibangunkannya jembatan Ampera dan memperlancar seluruh aktifitas masyarakat.

Perkembangan

Sosial-Budaya

Masyarakat Ulu

Perkembangan kehidupan sosial dan budaya masyarakat Ulu pasca dibangunnya jembatan Ampera sampai tahun 2010 telah mengalami perkembangan yang masih lambat. Seperti contoh dalam hal pelayanan yaitu pada tahun 1970-2000, masyarakat seberang Ulu 52\% kurang memadai dan tidak memadai 17\% (Wicaksono, 2003:80). Kondisi tersebut terdapat di kelurahan Karya Jaya, Kemang Agung, Keramasan, Kemas Rindo, 1 Ulu, 2 ulu, 5 Ulu, 7 Ulu, 15 Ulu, 11, ulu, 12, ulu 13 ulu, Tangga Takat, 16 ulu, Sentosa Plaju Talang Putri, Plaju Ilir. Sedangkan pelayanan masyarakat yang memadai berada pada kelurahan Kertapati, 3/4 Ulu, Silabranti, 14 Ulu, Komperta, dan Bagus Kunig.

Dalam hal kesehatan, 56\% masyarakat masih begantung pada pelayanan kesehatan di seberang Ilir dan 44\% masyarakat Ulu mengandalkan kesehatan di rumah sakit-rumah sakit yang berada di wilayah seberang Ulu. Dalam pelayanan kehidupan sosial, masyarakat Ulu masih memusat pada fasilitas-fasilitas sosial di wilayah Ilir. Seperti contoh setiap kegiatan sosial masyarakat dalam bentuk olahraga, meskipun wilayah Ulu memiliki stadiun 
di komplek Patra Plaju tetapi disetiap penyelengaraan even-even tertentu diadakan pada stadiun bumi Sriwijaya di wilayah Ilir.

Dengan kehidupan sosial seperti itu maka dalam perkembangan sosial masyarakat Ulu sepertinya akses jalan yang mudah untuk menyeberangai dari Ulu ke Ilir melalui jembatan Ampera masih belum memberikan noiali positif secara langsung. Tentu kondisi tersebut akan berkembang maju lebih baik tetapi membutuhkan proses yang panjang dan waktu yang lama untuk menyusun perubahan kehidupan sosial masyarakat Ulu.

Dalam masalah keamanan, wilayah Ulu tahun 1980-2003 masih terbilang rawan dengan tindak kriminal. Seperti berita dari Kompas (2003), yang menyatakan bahwasannya wilayah Ulu masih kurangnya penerangan jalan dan tempat-tempat umum dari sepanjang jalan Kertapati sampai jalan Plaju. Belum lagi hunian perumahanperumahan yang masih sedikit sehingga munculnya tindakan kriminal di wilayah ini sangat tinggi.

Menurut Mgs Ahmad Fauzi (tokoh masyarakat), wilayah Ulu sudah mulai tahun 1980-an sampai tahun 2000-an, memang julukan wilayah Ulu terutama wilayah sepanjang Kertapati, disebutsebut sebagai sarangnya orang-orang yang berbuat kriminal, orang Palembang sendiri menyebutnya sebagai kelompok wong preman. Tidak jarang setiap orang-orang yang melakukan kejahatan di pasar maupun di tempat-tempat umum seperti terminal dan stasiun, orang yang berbuat kejahatan tersebut selalu diidentikan orang dari seberang Ulu (Ketapati). Maka kesan yang tidak baik tersebut menjadikan wilayah Ulu atau Kertapati menjadi wilayah yang ditakuti bagi orang-orang yang dari luar wilayah Ulu.

Untuk tingkat pelaksanaan pendidikan, masyarakat Ulu masih masih berada di seberang Ulu untuk sekolah tingkat SD dan SMP tetapi untuk tingkat SMU sederajat $68 \%$ masih merujuk pada sekolah di seberang Ilir (Kota). Kondisi tersebut tentu beralasan karena bagi masyarakat Ulu sekolah untuk tingkat SMU di wilayah Ilir lebih berkualitas dan lebih maju dibandingkan dengan wilayah Ulu. Selain itu juga secara kuantitas pada tahun 1985-2000 sekolah tingkat SMU di wilayah Ulu masih sedikit, adapun ada yang lebih lengkap sekolah tingkat SMA berada di komplek Perusahaan Pertamina dan yang masuk di sekolah itu juga hanya orang-orang yang mampu atau anak pegawai dari Pertamina itu sendiri.

Dalam hal objek wisata, masyarakat Ulu kurang lebih 70\% masih mengarahkan ke seberang ilir, begitu juga untuk memenuhi kebutuhan barang dagangan seperti elektronik dan dagangan lainnya masih berkiblat di 
seberang Ulu. Kondisi demikian terjadi memang karena kondisi masyarakat Ulu yang belum tersentuh oleh kebijakan pemerintah pada masa itu baik dalam bidang ekonomi maupun objek wisata lainnya. Dan pada akhirnya setelah pasca tahun 2000-an, Palembang yang siap untuk menjadi tuan rumah PON yang ke XVI, maka Pemerintah mulai berbenah anatar Ulu dan Ilir sekan-akan ingin dijadikan sebagai objek yang penting dalam even-even besar kedepannya nanti.

\section{Perkembangan Ekonomi Masyarakat} Ulu

Masyarakat ulu yang secara geografis tidak jauh dari pusat kota dan pusat bisnis di seberang Ilir, hanya berjarak kurang lebih $2,5 \mathrm{~km}$, tetapi ironisnya pasca dibangunnya jembatan Ampera tahun 1962 sampai tahun 2000an, seluruh aktifitas jual beli memusat ke seberang Ilir yaitu di pasar 16 Ilir. Barang kali kondisi itu disebabkan karena wilayah Ilir masih dianggap ideal untuk dijadikan rujukan utama dalam bidang apapun sehingga masyrakat Ulu masih bergantung dengan kemajuan wilayah Ilir. Ditambahkan lagi menurut Mgs Ahmad Fauji, orang kalau mau pergi ke Ilir menyebutnya mau pergi ke Kota, padahal secara geografis wilayah Ulu hanya berjarak 2,5 km jaraknya dengan Ilir. Maka kondisi yang demikianlah yang menjadikan masyarakat Ulu masih belum berkembang dengan pesatnya meskipun jembatan Ampera sebagai penghubung antara kedua wilayah tersebut sudah dibangun cukup lama.

Untuk kawasan seberang ulu sendiri, masyarakatnya masih belum dapat membangun kepercayaan kepada para investasi dan usahawan. Kegiatan tersebut terbukti kegiatan perekonomian di wilayah 7 Ulu dan 10 Ulu masih banyak ruko-ruko atau tempat berdagang yang masih kosong pada masa itu. Sedangkan di wilayah Ilir sudah terbangun dengan pesatnya pasar-pasar tradisional maupun modern. Bisa jadi kondisi perekonomian masyarakt Ulu yang masih rendah karena faktor kurang percaya dirinya sebagai pengusaha yang seharusnya mampu untuk membangun perekonomian masyrakatnya yang lebih maju lagi dan jangan sampai bergantung kepada masyarakat Ilir.

Dalam penyedian lapangan kerja pasca dibangunnya jembatan Ampera masih belum mengalami peningkatan yang signifikan, hanya berubah sedikit saja. Masyarakat ulu sebagian besar masih melakukan pekerjaannya di wilayah Ilir sebagai penjaga toko atau pegawai di pabrik lainnya. Sedangkan industri-industri yang berada di Ulu belum mampu menyerap tenaga kerja lokal karena keterbatasan kemampuan dan keahlian, justru yang ditarik sebagai pekerja adalah orang-orang yang memiliki keahlian khusus dan 
keterampilan khusus, seperti contoh dalam permesinan dan perminyakan.

Pembangunan pasar di kota Palembang juga belum merata, baik pasar tradisional maupun pasar modern yaitu antara wilayah Ilir dan Ulu. Jumlah secara keseluruhan pemerintah dalam membangun pasar mencapai 22 pasar. Sebagian besar pasar dibangun dikawasan Ilir mencapai 17 pasar dan 5 pasar berada di seberang Ulu (Bappeda, 2001). Hal ini lah yang menyebabkan pemerataan perekonomian di wilayah Ulu tidak merata sehingga perkembang ekonomi hanya berjalan di tempat.

Pada tahun 1990 sampai 2000, perkembangan pembangunan central bisnis perekonomian masyarakat ulu masih belum mengalami perkembangan yang signifikan. Untuk wilayah Ilir sendiri sudah dibangun puluhan dan ratusan ruko disepanjang jalan Soederman dan puluhan hotel baru, tetapi untuk wilayah seberang Ulu masih berada di sekitar samping kanan kiri ujung jembatan Ampera wilayah Ulu dan sampai sepanjang pertemuan jalan arah kertapati dan Plaju.

\section{Pembahasan}

Pembangunan jembatan Ampera di sungai Musi merupakan langkah dari pemerintah yang sudah ideal dan dianggap sebagai kebijakan yang memihak kepada rakyat Palembang. Tetapi dalam perkembangannya, masyarakat Palembang merupakan masyarakat yang berkembang dan maju dengan latar belakang budayanya yang memiliki ciri khas tersendiri sesuai dengan perjalanan sejarahnya.

Untuk wilayah Ilir dan Ulu tentu sudah jelas ada sebuah pembeda yang mencolok pada masa sebelum dibangunnya jembatan Ampera, sampaisampai masyarakat dulu menyebutkan Ilir adalah wilayah Kota sedangkan wilayah Ulu adalah wilayah pinggiran, orang-orangnya yang masih pemikiran tradisional dan banyak lagi kesan-kesan yang negatif bagi masyarakat Ulu. Maka dengan dibangunnya jembatan Ampera pada tahun 1962, maka harapan semua orang akan perkembangan masyarakat Ulu dan Ilir akan lebih baik lagi dan lebih maju lagi. Tetapi sayangnya kondisi masyarakat Ulu dari tahun 1970-an sampai tahun masuk 2000-an, perkembangannya masih setengah jalan ditempat. Sehingga dengan demikian keberadaan jembatan Ampera yang diharapkan dapat membawa kemajuan bagi masyarakat Ulu masih belum terlaksana.

Kondisi demikian terbukti dengan perkembangan masyarakat Ulu baik dalam bidang sosial, budaya dan ekonomi masih belum ada perubahan. Masyarakat Ulu masih bergantung kepada masyarakat Ilir secara ekonomi, para pekerja masih memusat di wilayah Ilir, fasilitas-fasilitas sekolah dan 
fasilitas sosial lainnya juga masih memusat di wilayah Ilir. Dalam dunia pendidikan juga terlihat dari puluhan tahun masyarakat Ulu masih menganggap sekolah di llir masih menjadi primadona untuk melanjutkan sekolah ke tingkat menengah dan sederajat. Meskipun di wilayah Ulu ada sekolah yang maju tetapi tidak mencukupi kebutuhan, bisanya hanya diperuntukan bagi yang memiliki ekonomi tinggi atau anak-anak pegawai di Pertamina itu sendiri yang dapat sekolah di sekolah tersebut.

Tetapi berbeda ketika tahun 2000-an, pemerintah mulai melihat kesetrategisan wilayah Ulu untuk dijadikan wilayah reklamasi sebagai pusat-pusat perkantoran dan tempattempat objek olahraga lainnya. Kondisi tersebut terjadi karena kondisi wilayah Ilir yang semakin lama semakin sempit wilayahnya, maka pemerintah memutuskan untuk melakukan kebijakannya tersebut. Apa lagi jembatan Ampera sebagai akses utama penghubung antara Ulu dan Ilir sudah terbangun dengan peranannya. Maka ditambahkan lagi kota Palembang akan menjadi tuan rumah penyelengara PON ke XVI dan sekaligus perhelatan akbar olag raga Seagame, dengan demikan pemerintah kota Palembang dengan semangat membangun reklamasi wilayah Ulu dengan secepatnya.
Pengaruh keberadaan jembatan Ampera terhadap perkembangan masyarakat Ulu baik dalam bidang sosial, budaya dan ekonomi secara tidak langsung telah memberikan pengaruh, meskipun masih dalam skala yang rendah. Bagi masyarakat Ulu, jembatan Ampera adalah akses mereka yang ingin menyeberang ke wilayah Kota. Dengan proses yang lambat maka masyarakat Ulu secara tidak langsung dapat melihat kondisi masyarakat Ilir yang sudah maju dibandingkan dengan Ulu. Sehingga pada saatnya masyarakat Ulu ingin bangkit dengan ketertinggalannya, dengan terpinggirkannya hingga pada kondisi saat ini yang terus berkembang maju dengan berbagai kemajuannya.

\section{Kesimpulan}

Jembatan Ampera dibangun pada tahun 1962 yang menghubungkan antara seberang Ilir dan seberang Ulu Palembang. Pasca pembangunan jembatan Ampera, besar harapan masyarakat Ulu untuk menyeimbangkan pembangunan baik dalam bidang sosial, budaya dan ekonomi tetapi sayangnya perkembangan itu sangat lambat sekali sehingga kemajuan masyarakat Ulu masih dapat dikatakan berjalan ditempat.

Pada tahun 2000-an pemerintah Palembang mulai membuat kebijakan dalam perluasan wilayah karena padatnya penduduk di wilayah Ilir. 
Dengan keberadaan jembatan Ampera maka pemerintah kota Palembang merencanakan untuk membuat reklamasi wilayah seberang Ulu bagian rawa-rawa untuk dijadikan tempat perkantoran dan fasilitas olahraga lainnya. Tentu dengan keberadaan jembatan Ampera yang dapat menghubungkan wilayah Ulu dengan Ilir sedikit banyak memberikan dampak positif dalam bidang ekonomi, sosial dan budaya masyarakat Ulu meskipun kondisi tersebut baru berjalan pasca tahun 2000-an.

\section{DAFTAR PUSTAKA}

Akib, R.M. (1956). Kota Palembang 1272 Tahun dan 50 Tahun Kotapradja (Haminte) Palembang. Palembang: Rhama.

Arsip Nasional. No.361, hl. 14 dan Arsip Nasional Tahun 1943, hl. 24.

Alfitri, (2012). Situasi Sosial Kampung Kapiten dan Kampung Arab di Pinggiran Sungai Musi. Jurnal: Media Sosiologi Universitas Sriwijaya, Vol. 15. HIm. 30.

Amilda, dkk. (2012). Musi Menjalin Peradaban Warisan Budaya Sebagai Identitas. Palembang: Balai Arkeologi Palembang bekerja sama dengan Tunas Gemilang Press.

Abdurrahman, Dudung. (1999). Metode Penelitian Sejarah. Jakarta: Logos Wacana Ilmu.

Branch, Melville. (1996). Perencanaan Kota Komprehensif, Terj. Bambang Hari Wibisono, Gajah Mada University Prees.
Budihardjo, Eko. (1997). Tata Ruang Perkotaan, Bandung: Alumni.

Kedaulatan Rakyat, 19 Djuli 1960.

Irwanto, Dedi. (2010). Iliran dan Uluan : Dikotomi dan Dinamika Sejarah Kultural Palembang, Yogyakarta: Eja Publisher.

Irwanto, Dedi. (2011). Vanisia Dari Timur: Memaknai Produksi dan Reproduksi Simbolik Kota Palembang dari Kolonial sampai Pasca Kolonial. Yogyakarta: Penerbit Ombak.

Irwanto, Dedi. (2005). Mamang dan Belanda (Goresan-goresan Wajah Sosial-Ekonomi dan Kependudukan Sumatera Selatan Zaman Kolonial dan Refleksinya pada hari ini), Palembang:UNSRI.

Irwanto, Dedi. (2006). Laporan Penelitian: Politik Identitas Soekarno dan Ideologi (Imajinasi Sosial) Jembatan Ampera: Sebuah Simbolisme Palembang (Baru) 1945-1960 (Belum diterbitkan). Palembang: Univ. PGRI Palembang.

Ismail, Arlan. (2004). Marga di Bumi Sriwijaya : Sistem Pemerintahan, Kesatuan Masyarakat Hukum Daerah Uluan Sumatera Selatan, Palembang:Unanti Press.

Sjamsuddin, Helius. (2012). Metodologi Sejarah. Yogyakarta: Ombak.

Wicaksono. (2003). Kajian Perkembangan Kawasan Seberang Ulu Sebagai Arahan Pengembangan Kota Palembang bagian Selatan, Diponegoro: Univ. Diponegoro. 